\title{
SEASONAL TRENDS IN GROWTH AND BIOMASS \\ ACCUMULATION OF SELECTED NUTRIENTS \\ AND METALS IN SIX SPECIES OF EMERGENT AQUATIC MACROPHYTES
}

\section{Z 359}

\author{
L. L. Behrends, E. Bailey, M. J. Bulls, H.S. Coonrod \\ and F.J. Sikora
}

Constructed Wetlands Research Center, Tennessee Valley Authority, Muscle Shoals, Alabama 35660, USA

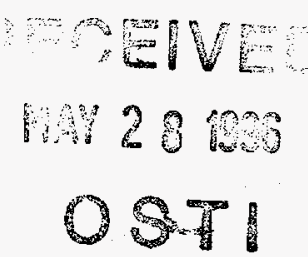

Growth and biomass accumualtion of selected nutrients and trace metals were monitored for six species of aquatic macrophytes during June, August and November, 1993. Plant species were cultivated in two polyculture treatments, each replicated three times. Polyculture I consisted of Scirpus acutus (hardstem bullrush), Phragmites communis (common reed), and Phalaris arundinacea (canary grass). Polyculture II consisted of Typha spp. (cattail), Scirpus atrovirens (green bullrush), and Scirpus cyperimus (wool grass). Each of the six cells ( $6 \times 9 \times 0.6 \mathrm{~m}$ ), was operated as a gravel-substrate, subsurface-flow wetlands in a continuous recirculating mode. At six week intervals, macro, micro and trace elements were dissolved and added to the sump of the recirculating system. On each of three sampling dates, replicate shoot and root samples were collected, segregated by species and tissue type (roots, rhizomes, stems and leaves), and prepared for gravimetric biomass estimates and chemical analysis. Tissue specific concentrations of N, P, K, $\mathrm{Ca}, \mathrm{Mg}, \mathrm{Fe}, \mathrm{Mn}, \mathrm{Zn}$ and $\mathrm{Cu}$. were determined on each date for each species and tissue type. Results will be discussed with respect to species specific growth rates, biomass accumulation, and seasonal uptake and translocation of plant nutrients.

\section{KEYWORDS}

Aquatic macrophytes; biomass; constructed wetlands; heavy metals; mesocosm; nutrients; root to shoot ratio; translocation;

\section{INTRODUCTION}

Emergent aquatic plants help to regulate water quality and concentrations of nutrients and other dissolved compounds in natural and constructed wetlands. Nutrient regulation is via plant uptake, biomass accumulation and modification of the rhizosphere to facilitate microbially mediated oxidation-reduction reactions (Steinberg and Coonrod 1994, Brix 1993, Armstrong et al. 1990, and Gersberg et al. 1986). Although uptake and storage of nutrients by aquatic macrophytes is relatively minor compared to storage and retention in wetland soils (Johnston 1991), their ability to assimilate and transform dissolved nutrients and other substances into stable organic compounds can result in significant improvements in the quality of surface waters. According to Reddy and DeBusk (1987), desirable traits of emergent macrophytes for waste water treatment include rapid growth, high biomass potential and the ability to assimilate and store nutrients for prolonged periods of time. Extensive data bases have been compiled which provide information related to rates of nutrient uptake, tissue specific nutrient concentrations and nutrient storage capacity for many of the floating and emergent macrophytes (Johnson 1991, Reddy and Debusk 1985). However, much of the information is derived from surface flow and natural wetland studies conducted at different locations, during different seasons and under widely differing environmental condition. In a recent technology assessment of subsurface flow constructed wetlands it was noted that there is a critical need for evaluating wetland plants other than cattails reeds and rushes (Reed 1993). 


\section{DISCLAMMIER}

Portions of this document may be illegible in electronic image products. Images are produced from the best available original document. 
I he Iennessee Valley Authority (TVA), has been involved in constructed wetlands research for nearly two decades evaluating their use for improving water quality from confined livestock operations, municipal wasteswaters, industrial wastewaters and acid mine drainage (Sikora 1994). In 1992 , a state-of-the-art constructed wetlands research facility was completed at Muscle Shoals, Alabama USA (Breed 1993). Layout and design of the complex (Fig. 1) facilitates multidiciplinary research related to the structure and function of subsurface flow constructed wetlands.

During 1993, a series of interdependent studies were conducted at the facility to better understand the dynamics of natural water purification processes which operate in subsurface-flow wetlands. This paper will summarize results related to seasonal growth and the assimilation and translocation of plant nutrients and heavy metals for six species of emergent aquatic macrophytes cultured in a recirculating subsurface flow wetland.

\section{MATERIALS AND METHODS}

This study and a companion study (Sikora 1994, were conducted during 1993 and early 1994 at the Tennessee Valley Authority's Constructed Wetlands R\&D Facility located in Muscle Shoals, Alabama . Climate at this southeastern US location is typified as temperate, with a 6 month growing season extending from mid-Aprii to mid-October.

Mesocosm cells used in this study were of two designs: cells constructed above ground level, which measured $6.1 \mathrm{~m}$ wide $\times 9.1 \mathrm{~m}$ long; and cells constructed below ground level, which measured $6.7 \mathrm{~m}$ wide and $9.8 \mathrm{~m}$ long. During construction, cells were double-lined with 30- and 40-mil-thick ultraviolet-resistant PVC to prevent leakage and groundwater infiltration. All cells were subsequently backfilled to a depth of $0.6 \mathrm{~m}$ with washed river gravel ranging from $1.6 \mathrm{~mm}$ to $25 \mathrm{~mm}$. Void space of the gravel was approximately 35 percent resulting in water volume capacities of 10.6 and $13.3 \mathrm{~m}^{3}$ for above- and belowground cells respectively. Six subsurface-flow mesocosm cells were used in this study (June 1 to November $15,1993)$, and operated in a batch-loaded-recirculating mode. All cells were drained and refilled with fresh riverwater prior to the study to ensure that residual fertilizer nutrients were eliminated. Recirculation flowrate during the study was maintained at $19 \mathrm{~L} / \mathrm{min}$. resulting in water turnover times of 11.6 and $9.3 \mathrm{~h}$ respectively for above and below ground cells. Automated flow switches were used to add fresh water to individual cells on a demand basis to replace water lost to evapotranspiration.

Plant species were cultivated in two polyculture treatments, each replicated three times. Polyculture I consisted of Scirpus acutus (hardstem bullnush), Phragmites communis (common reed), and Phalaris arundinacea (canary grass) ; Polyculture II consisted of Typha spp. (cattail), Scirpus atrovirens (green bullnush), and Scirpus cyperinus (wool grass). Transplants of S. acutus and S. atrovirens were established in June of 1991; the other four species were established in May of 1992. Each species was planted in rows with individual plants on $90 \mathrm{~cm}$ centers; rows were oriented perpendicular to the direction of water flow. Figure 2 illustrates cell configuration, flow pattern and planting arrangement of Polyculture I and II. Prior to the study period, plants were fertilized 3 to 4 times annually with ammonium nitrate, magnesium sulfate and triple thirteen $(13 \% \mathrm{~N}-13 \% \mathrm{p}-13 \% \mathrm{~K})$ at a rate sufficient to promote healthy plant growth.

At six week intervals (June 1, July 13, August 24, and October 5) a mixture of reagent grade chemicals and micro-nutrients were batch loaded into the recirculation sump of each cell to simulate water quality associated with domestic wastewater. Each cell received approximately $1 \mathrm{~kg}$ of a commercial micronutrient mix, $3.2 \mathrm{~kg}$ $\mathrm{MgSO}_{4}-\mathrm{H}_{2} \mathrm{O}, 3.8 \mathrm{~kg} \mathrm{NH}$ acetate, $1.5 \mathrm{~kg} \mathrm{~K}$ acetate and $0.8 \mathrm{~kg} \mathrm{KH}_{2} \mathrm{PO}_{4}$. Sikora et al (1994), summarizes techniques used in dissolving and adding nutrients to ensure rapid mixing and suppress $\mathrm{Mg}$ phosphate precipitation. Assuming complete dissolution and mixing of the compounds, initial concentrations of nutrients and metals were: $50 \mathrm{mg} / \mathrm{L}$ NH4-N, $15 \mathrm{mg} / \mathrm{L} \mathrm{P}, 112.5 \mathrm{mg} / \mathrm{L} \mathrm{C}, 62.3 \mathrm{mg} / \mathrm{L} \mathrm{K}, 25 \mathrm{mg} / \mathrm{L} \mathrm{Mg}, 32.8$ $\mathrm{mg} / \mathrm{L} \mathrm{S}, 0.19 \mathrm{mg} / \mathrm{L} \mathrm{B}, 0.09 \mathrm{mg} / \mathrm{L} \mathrm{Cu}, 1.2 \mathrm{mg} / \mathrm{L} \mathrm{Fe}, 0.1 \mathrm{mg} / \mathrm{L} \mathrm{Mn}, 0.09 \mathrm{mg} / \mathrm{L} \mathrm{Mo}$, and $0.6 \mathrm{mg} / \mathrm{L} \mathrm{Zn}$. Acetate compounds were added to provide a labile carbon source equivalent to $300 \mathrm{mg} / \mathrm{COD}$. 
On each of three sampling dates (June, August and November, 1993), replicate shoot and root samples were collected, segregated by species and tissue type (roots, rhizomes, stems and leaves), and prepared for gravimetric biomass estimates and chemical analysis according to procedures summarized by Jones and Case (1990). Tissue specific concentrations of $\mathrm{N}, \mathrm{P}, \mathrm{K}, \mathrm{Ca}, \mathrm{Mg}, \mathrm{Fe}, \mathrm{Mn}, \mathrm{Zn}$ and $\mathrm{Cu}$. were determined for each date for each species and tissue type. Plant tissues were segregated according to tissue type; root and rhizome materials were teased apart to remove rocks and then gently washed with tap water, oven dried at $70^{\circ} \mathrm{C}$ until a constant weight was obtained, weighed to the nearest $0.1 \mathrm{~g}$, and ground in a Wiley mill in preparation for chemical analysis. One gram subsamples were dry ashed at $470^{\circ} \mathrm{C}$ for $16 \mathrm{~h}$, digested in $3 \mathrm{M}$ $\mathrm{HCl}$ and filtered through Whatman no 42 filter paper. Filtrates were analyzed for $\mathrm{Mg}, \mathrm{Fe}, \mathrm{Zn}$ and $\mathrm{Cu}$ by atomic absorption spectroscopy. Concentrations of N P and $\mathrm{K}$ were determined according to procedures outlined by Page et al. (1982).

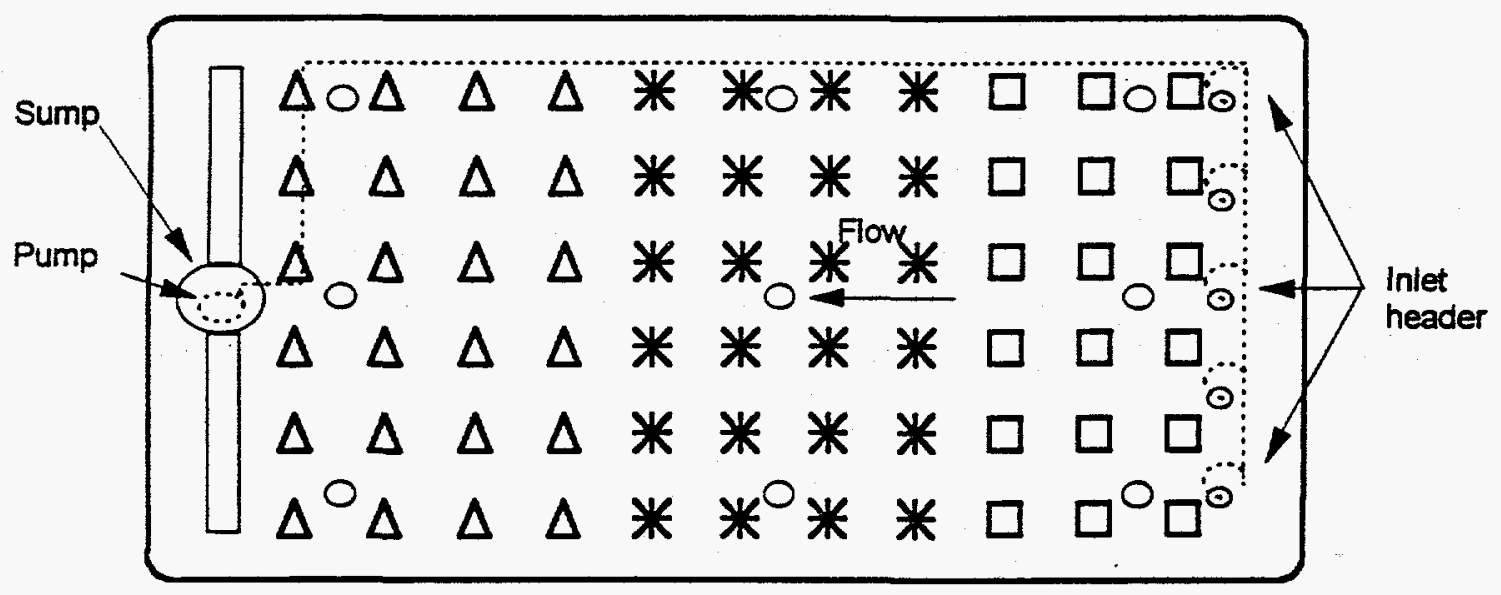

Fig. 2. Schematic diagram illustrating planting configuration with respect to subsurface flow design. Open squares designate location and planting rate (three rows with six plants per row) for hardstem bullrush (Polyculture 1) and cattails (Polyculture II). Stars (four rows with 6 plants per row) represent planting arrangement for common reed and green bullrush in Polyculture I and II respectively. Open triangles (four rows with six plants per row) represent canary grass and woolgrass in Polycultures I and II respectively.

Biomass estimates were made using two different procedures due to differences in species-specific growth habits. Whole-plant subsampling (cattails, woolgrass, green bullrush, and canary grass), was accomplished by selecting at random two plants of each species from each cell on each sample date. The plants were carefully bisected with one-half of the plant retained for analysis and the other half replanted. This procedure was used to minimize loss of plant material from the experiment. Care was taken to not select those particular plants on subsequent sampling dates. In the case of hardstem bullush and common reed, both of which have a spreading growth habit, it was not possible to discern individual plants. Thus it was necessary to subsample by removing shoot and root samples from two to three discreet $0.1 \mathrm{~m}^{2}$ sites. Relatively small subsamples were taken to minimize disturbance to the plant stand and to reduce potential impact on wetland functions. Auto-cad surveying equipment and associated computer software were used to plot perimeters and integrate areas of species-specific plant stands within each of the cells. Comparative dry matter biomass estimates ( $\mathrm{g}$ $\mathrm{dry}$ matter $/ \mathrm{m}^{2}$ ) were made by dividing total biomass estimates for each species within a mesocosm cell by the area occupied by that species within the cell. Total biomass estimates for the two polyculture treatments were calculated by simply summing the biomass estimates of the constituent species and dividing by the area of the cell. Mean estimates were weighted where appropriate to account for differences in either the frequecy of occurrence (number of samples having scenescent leaves, for example), or to adjust means due to differences in cell area (above ground vs below ground cells). Means and standard errors of the mean were calculated for biomass, nutrient and metal concentrations for each tissue-species combination for each of the 


\section{Biomass Estimates and Root to Shoot Ratios}

For purposes of this discussion, it is important to note that due to rapid recirculation and diurnal convective mixing, nutrients within cells were completely mixed, with little or no dead zones (Coonrod et al., unpublished data, Tennessee Valley Authority). Other studies (Edwards et al. 1993), have revealed that in conventional flow-through systems (non-recirculated), nutrient gradients may exist along the direction of water flow, leading to nutrient limitations and reduced plant growth in distal portions of the wetland cell. Since no discernable nutrient gradients existed within replicate cells of our study, we are assuming that direct species comparisons are possible, since species within and between poycultures were cultured in a "common" environment.

Table 1 provides summary data for each of the six species of aquatic macrophytes with respect to shoot, root, and total biomass for June, August and November, 1993. Over the course of the study, common reed, $P$. communis, exhibited the most rapid growth and biomass accumulation, with estimated final standing biomass exceeding 53 tons/ha. During the same time period and under similar conditions, final biomass accumulations for canary grass, $P$. arundinacea, and hardstem bull rush, $S$. acutus, were 9 and 28 tons/ha. respectively. In Polyculture II, final dry matter biomass values for cattail, $T$. spp., green bullrush, $S$. atrovirens, and woolgrass, $S$. cyperinus, were $7.5,8.0$ and 5.4 tons/ha. respectively. Total weighted biomass values in November for Polycultures I and II were 30.1 and 6.9 tons/ha respectively.

Clearly, common reed, $P$. communis, and hardstem bullrush, $S$. acutus, provided the greatest yield potential under the conditions of this study. Lakshman (1987) reported annual productivity data for $P$. communis and Scirpus spp. ranging from 4 to 61 and 2 to 25 tons/ha. Our yield data for $P$. communis and S. acutus fell within the upper portion of these ranges. Standing crop of cattails, T. spp. was near the bottom end of the range, 5 to 50 tons/ha, reported by Lakshman (1987). We have no explanation for the relatively poor productivity of cattails in this study.

We are also skeptical that our standing crop estimates for $P$. communis and $S$. acutus were actually as high as reported here. We projected standing crop of these species based on multiple small subsamples $\left(0.1 \mathrm{M}^{2}\right)$ and extrapolation based on total area of the plant stand. This assumes that plant coverage was uniform throughout the stand; visual observation confirmed however that this was not the case. Thus our projected yields may be overestimated by approximately 20-25 percent. Estimates for the other species however, were based on whole plant subsampling and extrapolation based on numbers of discrete plants per stand. We anticipate that these estimates are accurate.

Figure 3 provides seasonal data related to root and shoot biomass values for the six species evaluated. Of particular interest is both the quantity of biomass and how it was partitioned to above- and below-ground portions during the growing season. A major portion of biomass accumulation (new growth) of hardstem bullrush $S$. acutus, occurred prior to the June sampling period, with only moderate growth occurring in the late summer and early fall. However, relative growth of roots and shoots varied seasonally. In $S$. acutus, there was a shift in the root to shoot ratio from 0.75 (June) to 1.29 (November), indicating a reallocation of where photsynthate was being stored and where new growth was occuring. This shift in the root to shoot ratio is also correlated with the differential translocation of nutrients from shoot to root portions of the plant. Growth of common reed $P$. communis, was extremely rapid throughout the study. Root to shoot ratios for June, August and November averaged $0.27,0.77$, and 0.78 respectively. Relative growth of roots and shoots, and associated translocation of nutrients, varied both among species and among sampling periods. Five of the six species exhibited a seasonal increase in the root to shoot ratio. Only canary grass $P$. arundinacea, exhibited a decrease in the root to shoot ratio during the course of the study $(0.67$, June to 
Table 1. Mean dry matter biomes $(\mathrm{g} / \mathrm{m} 2)$ as a function of tissue, species and date. Each mean is based on 2-5 subsamples from each of three replicate cells. Tennessee Valley Authority, Muscle Shoals, Alabama

\begin{tabular}{cc} 
POLYCULTURE I & JUNE 1993 \\
\cline { 1 - 2 } Canary grass & $\frac{14}{\text { dry matter }(\mathbf{g} / \mathbf{m} 2)}$ \\
Senesced leaves & 125 \\
Green leaves & 330 \\
Green stems & 313 \\
Roots & 782
\end{tabular}

Common Reed

Senesced leaves

Senesced stems

Green leaves

Green stems

Roots

Roots and rhizomes

Rhizomes

Subtotal

Hardstem

Senesced leaves

Green leaves

Roots

Subtotal

Weighted Total

\section{POLYCULTURE II}

WOOLGRASS

Senesced leaves

Green leaves

Roots

Subtotal
G. BULLRUSH
Senesced leaves
Green leaves
Roots
Subtotal

CATTAIL

Senesced leaves

Green leaves

Roots

Roots/rhizomes

Subtotal

Weighted Total dry matter ( $g / m 2)$

247

884

712

162

554

2559

dry matter ( $\mathrm{g} / \mathrm{m} 2)$

507

1967

1869

4343

1751
AUGUST 1993

dry matter (g/m2)

8

675

73

394

1150

dry matter (g/m2)

456

418

833

1635

484

956

1110

5856

dry matter ( $g / m 2)$

762

1728

2457

4947

3452

AUGUST 1993

383

dry matter (g/m2)

49

207

150

406

dry matter (g/m2)

89

220

$-$

266

575

443
NOV. 1993

dry matter (g/m2)

738

93

626

1757

dry matter (g/m2)

2010
1711
2335
-
4731
-
10787

dry matter (g/m2)

1334

1108

3153

5595

6029 dry matter (g/m2)

28

355

254

637

NOV. 1993

dry matter (g/m2)

512

579

1091

dry matter (g/m2)

50

655

138

843

dry matter (g/m2)

28

454

33

261

776

749 dry matter (g/m2)

930

675

1605

dry matter (g/m2)

630

867

1497

1386 
Tables 2 and 3 summarize tissue specific concentrations of $\mathrm{N}, \mathrm{P}, \mathrm{K}, \mathrm{Ca}$, and $\mathrm{Mn}$ for each of six species on three sampling dates. With respect to the major plant nutrients, $N$ and $P$, tissue concentrations were within the narrow ranges reported for $\mathrm{N}(1-3 \%)$ and $\mathrm{P}(0.1$ to $0.3 \%)$, for wetland species (Johnston 1991). Generaily, nutrient concentrations were highest in early June in the above ground tissues, with green leaves having the highest concentrations of $\mathrm{N}$ and $\mathrm{P}$ followed by green stems and roots/rhizomes. Senescing tissues usually had significantly reduced levels of $\mathrm{N}$ and $\mathrm{P}$, but often had elevated levels of $\mathrm{K}$ and $\mathrm{Ca}$ possibly pointing to their importance as structural components of lignin and cellulose. Concentration of Mn ranged from 0.1 to 0.2 percent, with little variation between species, tissues or sampling dates.

\section{ROOTISHOOT DATA}

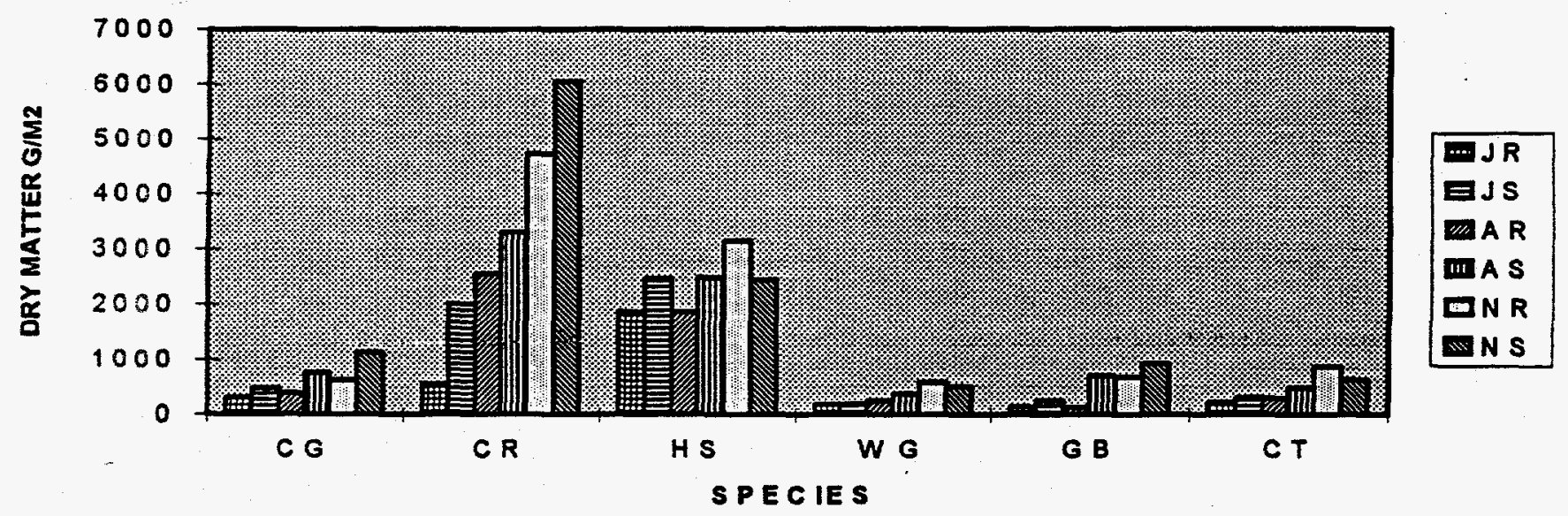

Figure 3. Dry matter root/shoot relationships for six species of aquatic macrophytes. Species evaluated were: canary grass (CG), common reed cane (CR), hardstem bullrush (HS), woolgrass (WG), green bullrush (GB), and cattail (CT). Data bars reflect dry matter $(\mathrm{g} / \mathrm{m} 2)$ for root $(\mathrm{R})$ and shoot $(\mathrm{S})$ tissues for sampling periods June $(J)$, August $(A)$ and November $(N)$.

Elevated levels of nutrients in the shoot portion of the plant during June can be attributed to upward translocation ( root to shoot), and luxury consumption of essential nutrients during the early spring growth period (Martin and Fernandez1992, Reddy and DeBusk 1987, and Boyd 1970). These dynamic processes c also help to explain the tissue specific nutrient concentrations during the August and November sampling periods, which in most cases were less than tissue concentrations observed in June. As biomass continued to accumulate during July and August, luxury-consumed nutrients were translocated to new growth and/or to the root/rhizome complex, thus diluting the above ground tissue concentration of major nutrients. Boyd (1970), reported that in T. latifolia, this process is also due to a decrease in the rate of nutrient absorbtion per unit of dry matter production during the post spring growth period.

During the course of the study, many of the nutrients were apparently translocated from the leaves and stems to the roots and rhizomes. Leaf tissue concentrations of $\mathrm{N}$ and $\mathrm{P}$ often decreased by as much as 25 to $75 \%$ while root tissue concentrations of these nutrients increased by similar amounts. Timing and degree of translocation appeared to vary on a species-specific basis (Tables 2 and 3). These factors may be of importance in selecting species for polyculture compatibility, as variation in timing of growth, nutrient uptake, and translocation may influence interspecific competition and polyculture efficiency. 
Table 2. Nutrient concentrations (means +/- 1 S.E.) for three species of aquatic macrophytes as a function of tissue type and season of year. Results are reported on a dry matter basis. Each mean is based on 1-2 subsamples from each of three replicate cells. Tennessee Valley Authority, Muscle Shoals, Alabama.

JUNE 1993

Canary grass

Senesced leaves

Green leaves

Green stems

Roots

Common Reed

Senesced stems

Green leaves

Green stems

Roots

Rhizomes

Hardstem

Senesced stems

Green leaves

Roots

AUGUST, 1993

Canary grass

Senesced leaves

Green leaves

Green stems

Roots

Common Reed

Senesced leaves

Senesced stems

Green leaves

Green stems

Roots

Rhizomes

Hardstem

Senesced leaves

Green leaves

Roots

NOV. 1993

Canary grass

Green leaves/stems

Roots

Common Reed

Senesced stems

Green leaves

Green stems

Roots/thizomes

Hardstem

Senesced leaves

Green leaves

Roots

$$
\text { N (\%) }
$$

$1.3(-)$

$2.8(0.12)$

$1.2(0.09)$

$1.3(0.09)$

$0.5(0.05)$

$2.4(0.1)$

$1.2(0.14)$

$1.2(0.12)$

$1.2(0.12)$

$0.7(0.09)$

$1.4(0.08)$

$1.0(0.11)$

N (\%)

$1.2(-)$

$1.5(0.32)$

$0.9(-)$

$1.2(0.1)$

$1.1(0.11)$

$0.5(0.04)$

$2.1(0.07)$

$0.9(0.04)$

$1.2(0.03)$

$1.0(0.07)$

$0.8(0.11)$

$1.3(0.09)$

$1.0(0.09)$

N(\%)

$1.6(0.14)$

$1.4(0.11)$

$0.9(0.15)$

$1.9(0.1)$

$0.8(0.1)$

$1.2(0.1)$

$0.8(0.10)$

$1.3(0.13)$

$1.8(0.12)$

\section{P (\%)}

$0.1(-)$

$0.3(0.03)$

$0.2(0.03)$

$0.2(0.03)$

$0.0(0.02)$

$0.2(0.0)$

$0.2(0.0)$

$0.1(0.02)$

$0.2(0.0)$

$0.1(0.0)$

$0.2(0.03)$

$0.2(0.00)$

$\underline{P(\%)}$

$0.1(-)$

$0.2(0.03)$

$0.1(-)$

$0.2(0.02)$

$0.1(0.1)$

$0.0(0.02)$

$0.2(0.02)$

$0.1(0.00)$

$0.1(0.03)$

$0.2(0.04)$

$0.1 .(0.00)$

$0.2(0.03)$

$0.2(0.02)$

$\underline{\mathbf{P}(\%)}$

$0.2(0.02)$

$0.2(0.02)$

$0.1(0.00)$

$0.1(0.02)$

$0.1(0.00)$

$0.2(0.02)$

$0.1(0.02)$

$0.2(0.03)$

$0.3(0.03)$
K (\%)

$0.6(-)$

$2.0(0.07)$

$1.5(0.13)$

$0.6(0.07)$

$0.3(0.09)$

$2.3(0.17)$

$2.0(0.18)$

$0.9(0.11)$

$1.1(0.10)$

$0.3(0.05)$

$2.7(0.18)$

$0.7(0.07)$

$\underline{\mathrm{K}(\%)}$

$0.1(-)$

$1.4(0.34)$

$1.4(-)$

$0.8(0.07)$

$0.6(0.11)$

$0.5(0.17)$

$1.8(0.06)$

$0.9(0.16)$

$0.8(0.23)$

$1.0(0.30)$

$1.1(0.26)$

$2.4(0.37)$

$0.9(0.08)$

K(\%)

$1.2(0.12)$

$0.6(0.07)$

$2.1(0.17)$

$1.0(0.15)$

$0.7(0.00)$

$0.8(0.08)$

$0.6(0.05)$

$2.3(0.33)$

$1.0(0.09)$
$\mathrm{Ca}(\%)$

Mn (\%)

$0.3(-)$

$0.4(0.06)$

$0.2(0.07)$

$0.3(0.03)$

$0.2(0.14)$

$0.4(0.04)$

$0.1(0.0)$

$0.4(0.06)$

$0.0(0.0)$

$0.8(0.11)$

$0.3(0.04)$

$0.3(0.06)$

$\mathrm{Ca}(\%)$

$$
\begin{array}{r}
0.1(-) \\
0.3(0.05) \\
0.1(-) \\
0.5(0.08)
\end{array}
$$

$0.5(0.08)$

$0.2(0.04)$

$0.3(0.02)$

$0.1(0.06)$

$0.3(0.07)$

$0.1(0.05)$

$1.1(0.16)$

$0.4(0.06)$

$0.7(0.22)$

Ca $(\%)$

$0.2(0.02)$

$0.8(0.17)$

$0.2(0.05)$

$0.2(0.04)$

$0.1(0.12)$

$0.1(0.05)$

$0.6(0.02)$

$0.3(0.03)$

$0.3(0.09)$
$0.1(-)$

$0.2(0.03)$

$0.1(0.0)$

$0.1(0.03)$

$0.0(0.0)$

$0.2(0.01)$

$0.0(0.0)$

$0.1(0.0)$

$0.0(0.0)$

$0.0(0.0)$

$0.1(0.0)$

$0.1(0.02)$

\section{Mn (\%)}

$$
\begin{array}{r}
0.0(-) \\
0.1(0.00) \\
0.1(-) \\
0.0(0.02)
\end{array}
$$

$0.1(0.01)$

$0.0(0.00)$

$0.1(0.00)$

$0.0(0.00)$

$0.1(0.03)$

$0.0(0.00)$

$0.1(0.03)$

$0.1(0.02)$

$0.1(0.00)$

Mn (\%)

$0.1(0.00)$

$0.1(0.02)$

$0.1(0.05)$

$0.1(0.00)$

$0.0(0.03)$

$0.1(0.02)$

$0.1(0.00)$

$0.1(0.01)$

$0.1(0.00)$ 
Table 3. Nutrient concentrations (means $+/$ - 1 S.E.) for three species of aquatic macrophytes as a function of tissue type and season of year. Results are reported on a dry matter basis. Each mean is based on 1-2 subsamples from each of three replicate cells. Tennessee Valley Authority, Muscle Shoals, Alabama.

JUNE 1993

WOOLGRASS

Senesced leaves

Green leaves

Roots

G. BULLRUSH

Senesced leaves

Green leaves

Roots

CATTAIL

Senesced leaves

Green leaves

Roots

AUGUST, 1993

WOOLGRASS

Senesced leaves

Green leaves

Roots

G. BULLRUSH

Senesced leaves

Green leaves

Roots

CATTAIL

Senesced leaves

Green leaves

Roots

Rhizomes

NOV. 1993

WOOLGRASS

Green leaves

Roots

G. BULLRUSH

Green leaves

Roots

CATTAIL

Green leaves

Roots

$\mathbf{N ( \% )}$
$0.8(0.05)$
$1.6(0.08)$
$1.3(0.14)$

$1.1(0.08)$

$1.5(0.07)$

$1.6(0.09)$

$0.7(0.09)$

$1.7(0.12)$

$1.4(0.14)$

$\mathrm{N}(\%)$

$1.0(0.07)$

$1.4(0.04)$

$1.2(0.08)$

$1.2(0.07)$

$1.4(0.07)$

$1.6(0.17)$

$0.8(0.1)$

$1.5(0.14)$

$0.9(0.08)$

$1.4(0.12)$

$$
\begin{gathered}
\mathbf{P ( \% )} \\
0.1(0.03) \\
0.2(0.0) \\
0.2(0.03)
\end{gathered}
$$

$0.1(0.0)$

$0.2(0.0)$

$0.2(0.02)$

$0.1(0.0)$

$0.2(0.03)$

$0.3(0.03)$

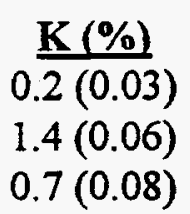

$0.5(0.09)$

$2.4(0.30)$

$1.0(0.21)$

$0.6(0.09)$

$2.2(0.11)$

$1.3(0.25)$

$$
\begin{gathered}
\mathrm{Ca}(\%) \\
0.6(0.10) \\
0.3(0.03) \\
0.2(0.0)
\end{gathered}
$$

$1.1(0.09)$

$0.3(0.02)$

$0.4(0.06)$

$1.5(0.06)$

$0.9(0.07)$

$0.7(0.03)$
Mg(\%)

$0.1(0.0)$

$0.1(0.03)$

$0.1(0.0)$

$0.2(0.03)$

$0.1(0.0)$

$0.1(0.0)$

$0.1(0.03$

$0.1(0.0)$

$0.2(0.02)$

\begin{tabular}{ll} 
Ca $(\%)$ & $\underline{\operatorname{Mg}(\%)}$ \\
\hline $0.0(-)$ & $0.1(0.02)$ \\
$0.0(-)$ & $0.2(0.0)$ \\
$0.0(-)$ & $0.1(0.0)$
\end{tabular}

\section{P(\%) \\ $0.2(0.0)$ \\ $0.2(0.2)$}

$0.1(0.02)$

$0.2(0.02)$

$0.3(0.03)$

$0.10(0.0)$

$0.20(0.02)$

$0.2(0.02)$

$0.3(0.04)$
K $(\%)$

$0.5(0.05)$

$2.2(0.16)$

$1.0(0.08)$

$1.2(0.21)$

$2.9(0.06)$

$1.2(0.07)$

$0.8(0.20)$

$2.3(0.15)$

$2.2(0.30)$

$1.8(0.25)$
$0.9(0.11)$

$0.4(0.02)$

$0.5(0.10)$

$0.9(0.20)$

$.0 .9(0.08)$

$0.8(0.07)$

$0.6(0.05)$
$0.1(0.01)$

$0.1(0.0)$

$0.1(0.0)$

$0.1(0.0)$

$0.1(0.0)$

$0.1(0.02)$

$0.1(0.0)$
$\frac{\mathrm{N}(\%)}{2(0.04)}$
$1.5(0.05)$

$1.2(0.05)$

$1.9(0.08)$

$0.9(0.08)$

$1.7(0.07)$
P (\%)

$0.1(0.02)$

$0.2(0.02)$

$0.2(0.02)$

$0.3(0.02)$

$0.1(0.02)$

$0.3(0.02)$
K $(\%)$

$1.3(0.46)$

$0.8(0.06)$

$2.5(0.45)$

$1.1(0.05)$

$1.3(0.50)$

$1.2(0.11)$
$\mathrm{Ca}(\%)$

$0.4(0.06)$

$0.3(0.03)$

$0.5(0.05)$

$0.3(0.03)$

$1.3(0.15)$

$0.5(0.05)$
Mg (\%)

$0.2(0.02)$

$0.1(0.0)$

$0.1(0.01)$

$0.1(0.0)$

$0.1(0.0)$

$0.2(0.01)$ 
With respect to species differences, it can be seen that the common reed, P.communis, generally had higher concentrations of $\mathrm{N}$ and $\mathrm{P}$ in above and below ground tissues than the other species. This factor, coupled with its significantly faster growth rate, resulted in this species having superior abilities with repect to uptake and storage of nutrients under the conditions of this study. Hardstem bullrush, $S$. acutus, although not having $\mathrm{N}$ and $\mathrm{P}$ tissue concentrations as high as $P$. communis, should also be evaluated further because of its rapid growth early in the spring. Canary grass, $P$. arundinacea, exhibited high $\mathrm{N}$ and $\mathrm{P}$ concentrations, but yield was significantly less than common reed or hardstem bullrush. Both of the latter species have a spreading growth habit, while canary grass has a clumping (non-spreading); growth habit. Additional studies should be conducted to evaluate the impact of planting density on yield of spreading vs clumping species. None of the species within Polyculture II had exceptional tissue nutrient levels. However, analysis of specific growth rates (increase in biomass per unit time) indicate that green bullrush had a relatively rapid growth rate. Final standing crop of woolgrass ( $S$. cyperimus) and green bulliush ( $S$. atrovirens), may have been negatively impacted by their growth habit (clumping vs spreading) and relatively low planting densities.

\section{Metals Content: Root and Shoot Concentrations}

The metals $\mathrm{Fe} \mathrm{Mn,} \mathrm{Zn}$ and $\mathrm{Cu}$ were added to the system as micronutrients, and hence at relatively low concentrations: $\mathrm{Fe}(1.2 \mathrm{mg} / \mathrm{l}), \mathrm{Mn}(0.1 \mathrm{mg} / \mathrm{l}), \mathrm{Zn}(0.6 \mathrm{mg} /)$, and $\mathrm{Cu}(0.09)$. Tables 4 and 5 summarize mean metal concentrations (ug/g dry tissue), for root and shoot tissues for each of the six aquatic macrophytes for each sampling date. The most striking aspect of our results was the high concentration of $\mathrm{Fe}$ and $\mathrm{Mn}$ in the root tissues of all six species (Figures 4-7) At the time of sampling, it was observed that many of the roots, especially those of cattail and canary grass, were encrusted with a dark pigmented layer. We speculate that this material was composed of $\mathrm{Fe}$ and $\mathrm{Mn}$ oxides, derived abiotically, which have been shown to form thin concretions on the surface of oxygen-bathed root tips of aquatic plants (Faulkner and Richardson 1994). Armstrong (1975), has suggested that oxygen diffusion from root tips of aquatic plants is an important mechanism for reoxidizing and precipitating reduced ions, such as $\mathrm{Mn}^{+2}$, which in anoxic zones can be toxic to plants.

Root tissue concentrations of $\mathrm{Fe}$ and Mn were often 10-40 times higher than shoot tissue concentrations (Fig. 4 -7). Root tissue concentration of $\mathrm{Fe}$ had a strong species $\mathrm{x}$ season interaction. For example, canary grass root tissue concentrations of iron increased in a linear fashion over the course of the growing season, increasing from a mean of $2445 \mathrm{ug} / \mathrm{g}$ in June to over 8,300 in November (fig. 4). In contrast, common reed root tissue concentration decreased from 4500 to less than $2800 \mathrm{ug} / \mathrm{g}$ during the same time period (Table 4, Fig. 4). Species evaluated in Polyculture $I$ also exhibited strong species $x$ season interactions. Cattail root tissue concentration of $\mathrm{Fe}$ experienced a dramatic peak (.7,400 ug/g) in August (Fig. 5). However, it should be noted that this mean was associated with a high degree of variability (S.E. $=2214 \mathrm{ug} / \mathrm{g}$, Table 5). High levels of intra- and inter-specific variation, with respect to metals removal, may be influenced by factors such as season, age of the root mass, root to shoot to rhizome ratios, rate at which oxygen is diffusing into the rhizosphere, and species-specific root/microbial associations (Steinberg and Coonrod 1994).

Iron concentrations in the root biomass were approximately ten time higher than manganese concentrations, possibly reflecting the order of magnitude difference in their initial dosing concentrations. However, it has also been reported that in a constructed wetlands environment, iron is removed much more rapidly than manganese (Faulkner and Richardson (1994). Note also that the relative extent and direction of the species $\mathrm{x}$ season interactions are similar for both Fe and Mn (Fig. 4 vs 6 and 5 vs 7). This indicates that the underlying mechanism(s) for $\mathrm{Fe}$ and $\mathrm{Mn}$ removal in the root zone are the same or are correlated.

Initial loading rates $(\mathrm{mg} / \mathrm{l})$ of $\mathrm{Zn}(0.6)$ and $\mathrm{Cu}(0.09)$ into the mesocosms were similar to loading rates for $\mathrm{Fe}$ (1.2) and $\mathrm{Mn}(0.1)$, respectively. However, concentrations of $\mathrm{Zn}$ and $\mathrm{Cu}$ in root and shoot tissues werel to 2 orders of magnitude less than those observed for $\mathrm{Fe}$ and $\mathrm{Mn}$. However, unlike $\mathrm{Fe}$ and $\mathrm{Mn}$, tissue distributions of $\mathrm{Zn}$ and $\mathrm{Cu}$ were relatively evenly distributed among root and shoot tissues (Table 4 and 5). 
Table 4. Metal concentrations (means $+/-1$ S.E.) for three species of aquatic macrophytes as a function of tissue type and season of year. Results are reported on a dry matter basis. Each mean is based on 1-2 subsamples from each of three replicate cells. Tennessee Valley Authority, Muscle Shoals, Alabama.

\begin{tabular}{|c|c|c|c|c|}
\hline JUNE, 1993 & $\mathrm{Fe}(\mathrm{ug} / \mathrm{g})$ & Mn (ug/g) & $\underline{\operatorname{Zn}(u g / g)}$ & $\mathrm{Cu}(\mathrm{u} g / \mathrm{g})$ \\
\hline \multicolumn{5}{|l|}{ Canary grass } \\
\hline Senesced leaves & $190(-)$ & $205(-)$ & $15(-)$ & $2.0(-)$ \\
\hline Green leaves & $89(8)$ & $93(4.2)$ & $20(1.5)$ & $3.4(0.5)$ \\
\hline Green stems & $54(14)$ & 64 (17.9) & $12(2.7)$ & $1.6(0.5)$ \\
\hline Roots & $2445(675)$ & $385(86)$ & $29(0.7)$ & $9.7(1.2)$ \\
\hline \multicolumn{5}{|l|}{ Common Reed } \\
\hline Senesced stems & $57(12)$ & $70(8.7)$ & $15(3.2)$ & $0.7(0.3)$ \\
\hline Green leaves & $161(36)$ & $153(43.6)$ & $21(1.9)$ & $4.4(0.7)$ \\
\hline Green stems & $35(4)$ & $47(6.6)$ & $37(2.7)$ & $3.6(0.8)$ \\
\hline Roots & $4547(426)$ & $703(87)$ & $30(1.4)$ & $10.8(1.0)$ \\
\hline Rhizomes & $325(33)$ & $68(11.2)$ & $18(2.0)$ & $2.7(0.6)$ \\
\hline \multicolumn{5}{|l|}{ Hardstem } \\
\hline Senesced leaves & $147(49\}$ & $330(55.5)$ & $24(5.4)$ & $1.3(0.4)$ \\
\hline Green leaves & $47(6)$ & $249(61.3)$ & $13(1.3)$ & $3.1(0.1)$ \\
\hline Roots & $2344(203)$ & $505(41.3)$ & $14(1.3)$ & $6.9(1.5)$ \\
\hline AUGUST. 1993 & $\mathrm{Fe}(\mathrm{ug} / \mathrm{g})$ & $\underline{\operatorname{Mn}}(\mathrm{ug} / \mathrm{g})$ & $\operatorname{Zn}(u g / g)$ & $\mathrm{Cu}(\mathrm{ug} / \mathrm{g})$ \\
\hline \multicolumn{5}{|l|}{ Canary grass } \\
\hline Senesced leaves & $771(-)$ & $450(-)$ & $22(-)$ & $2(-)$ \\
\hline Green leaves & $175(71)$ & $240(111.2)$ & $20(4.4)$ & $1(0.2)$ \\
\hline Green stems & $66(12)$ & $117(43)$ & $15(2.5)$ & $1(0.1)$ \\
\hline Roots & $4555(883)$ & $388(56.9)$ & $48(17.2)$ & $5(0.6)$ \\
\hline \multicolumn{5}{|l|}{ Common Reed } \\
\hline Senesced leaves & $178(23)$ & $245(23.6)$ & $46(8.6)$ & $3(0.3)$ \\
\hline Senesced stems & $91(30)$ & $86(6.8)$ & $24(7.9)$ & $1(0.3)$ \\
\hline Green leaves & $115(10)$ & $394(17.0)$ & $28(3.7)$ & $2(0.3)$ \\
\hline Green stems & $39(7)$ & $137(13.8)$ & $45(9.7)$ & $2(0.2)$ \\
\hline Roots & $2728(870)$ & 479 (153) & $62(32)$ & $9(2.2)$ \\
\hline Rhizomes & $163(50)$ & $106(29.4)$ & $23(3.5)$ & $2(0.5)$ \\
\hline \multicolumn{5}{|l|}{ Hardstem } \\
\hline Senesced leaves & $138.6(24)$ & $669(132.6)$ & $15(8.9)$ & $3(0.2)$ \\
\hline Green leaves & $58(7)$ & $528(98.6)$ & $19(4.2)$ & $2(0.3)$ \\
\hline Roots & $1820(226)$ & $489(65.1)$ & $23(5.9)$ & $5(0.5)$ \\
\hline NOV. 1993 & $\mathrm{Fe}(\mathrm{ug} / \mathrm{g})$ & $\operatorname{Mn}(\mathrm{ug} / \mathrm{g})$ & $\underline{Z n}(\mathrm{ug} / \mathrm{g})$ & $\mathrm{Cu}(\mathrm{ug} / \mathrm{g})$ \\
\hline \multicolumn{5}{|l|}{ Canary grass } \\
\hline Green leaves/stems & $309(70)$ & $312(39)$ & $14(0.7)$ & $2(0.4)$ \\
\hline Roots & $8352(953)$ & $1033(251.1)$ & $43(9.5)$ & $6(0.7)$ \\
\hline \multicolumn{5}{|l|}{ Common Reed } \\
\hline Senesced stems & $77(11)$ & $142(39.3)$ & $26(13.1)$ & $2(0.9)$ \\
\hline Green leaves & $112(5)$ & $457(39.2)$ & $17(1.6)$ & $1(0.2)$ \\
\hline Green stems & $51(8)$ & $123(10.4)$ & 11.(2.0) & $1(0.5)$ \\
\hline $\begin{array}{l}\text { Roots/ rhizomes } \\
\text { Hardstem }\end{array}$ & $2533(655)$ & $561(134.5)$ & $19(1.5)$ & $3(0.6)$ \\
\hline Senesced leaves & $213(28)$ & $953(135)$ & $13(2.1)$ & $2(1.0)$ \\
\hline Green leaves & $107(14)$ & 879 (197) & $14(2.5)$ & $1(0.3)$ \\
\hline Roots & $2754(121)$ & $1143(144)$ & $18(0.9)$ & $4(0.7)$ \\
\hline
\end{tabular}


Table 5. Metal concentrations (means $+/-1$ S.E.) for three species of aquatic macrophytes as a function of tissue type and season of year. Results are reported on a dry matter basis. Each mean is based on 1-2 subsamples from each of three replicate cells. Tennessee Valley Authority, Muscle Shoals, Alabama.

\begin{tabular}{|c|c|c|c|c|}
\hline JUNE, 1993 & $\mathrm{Fe}(\mathrm{ug} / \mathrm{g})$ & Mn (ug/g) & $\operatorname{Zn}(u g / g)$. & $\mathrm{Cu}(\mathbf{u g} / \mathrm{g})$ \\
\hline$\overline{\text { WOOLGRASS }}$ & & & & \\
\hline Senesced leaves & $304(55.7)$ & $162(14.2)$ & $33(10.7)$ & $1(0.4)$ \\
\hline Green leaves & $83(12.4)$ & $140(23.8)$ & $16(2.1)$ & $2(0.2)$ \\
\hline Roots & $1185(188.1)$ & $113(20.4)$ & $15(1.5)$ & $6(1.8)$ \\
\hline \multicolumn{5}{|l|}{ G. BULLRUSH } \\
\hline Senesced leaves & $387(63.3)$ & $230(41.3)$ & $33(4.7)$ & $3(0.5)$ \\
\hline Green leaves & $124(42.1)$ & $189(51.8)$ & $13(1.4)$ & $2(0.3)$ \\
\hline Roots & $2131(582.2)$ & $296(63.0)$ & $22(1.5)$ & $8(1.0)$ \\
\hline \multicolumn{5}{|l|}{ CATTAL } \\
\hline Senesced leaves & $164(27.8)$ & $139(30.7)$ & $21(2.5)$ & $2(0.4)$ \\
\hline Green leaves & $45(5.4)$ & $244(34.8)$ & $15(1.8)$ & $3(0.3)$ \\
\hline Roots & $1011(203.8)$ & $153(17.5)$ & $17(2.8)$ & $6(1.4)$ \\
\hline AUGUST, 1993 & $\mathrm{Fe}(\mathrm{ug} / \mathrm{g})$ & $\mathrm{Mn}(\mathrm{ug} / \mathrm{g})$ & $\underline{\operatorname{Zn}(\mathrm{ug} / \mathrm{g})}$ & $\mathrm{Cu}$ (ug/g) \\
\hline \multicolumn{5}{|l|}{$\overline{\text { WOOLGRASS }}$} \\
\hline Senesced leaves & $257(33.5)$ & $419(47.9)$ & $13(2.4)$ & $2(0.2)$ \\
\hline Green leaves & $83(8.4)$ & $404(75.6)$ & $11(0.7)$ & $1(0.2)$ \\
\hline Roots & $1621(187.5)$ & $199(28.9)$ & $14(0.9)$ & $4(0.4)$ \\
\hline \multicolumn{5}{|l|}{ G. BULLRUSH } \\
\hline Senesced leaves & $370(100.7)$ & $504(28.9)$ & $18(2.0)$ & $2(0.2)$ \\
\hline Green leaves & $83(8.4)$ & $320(22.7)$ & $10(0.6)$ & $2(0.2)$ \\
\hline Roots & $1755(354.4)$ & $355(47.8)$ & $17(1.6)$ & $5(1.0)$ \\
\hline \multicolumn{5}{|l|}{ CATTAIL } \\
\hline Senesced leaves & $148(58.1)$ & $521(205.6)$ & $19(1.9)$ & $2(0.2)$ \\
\hline Green leaves & $58(5.0)$ & $600(94.5)$ & $12(0.8)$ & $3(0.2)$ \\
\hline Roots & $7437(2214.2)$ & $843(143.4)$ & $38(2.8)$ & $8(1.2)$ \\
\hline Rhizomes & $804(98.5)$ & $215(24.5)$ & $19(1.1)$ & $3(0.2)$ \\
\hline NOV. 1993 & $\mathrm{Fe}$ (ug/g) & $\operatorname{Mn}(\mathrm{ug} / \mathrm{g})$ & $\operatorname{Zn}(\mathbf{u g} / \mathrm{g})$ & $\mathrm{Cu}$ (ug/g) \\
\hline \multicolumn{5}{|l|}{ WOOLGRASS } \\
\hline Green leaves & $723(185.2)$ & $673(90.3)$ & $15(3.6)$ & $1(0.4)$ \\
\hline Roots & $2228(348.6)^{\prime}$ & $368(32.8)$ & $17(1.4)$ & $3(0.3)$ \\
\hline \multicolumn{5}{|l|}{ G. BULLRUSH } \\
\hline Green leaves & $297(55.2)$ & $657(54.3)$ & $13(1.2)$ & $2(0.4)$ \\
\hline Roots & $2373(416.2)$ & $588(84.2)$ & $29(6.2)$ & $4(0.5)$ \\
\hline \multicolumn{5}{|l|}{ CATTAIL } \\
\hline Green leaves & $142(25.7)$ & $613(77.1)$ & $19(4.2)$ & $3(0.7)$ \\
\hline Roots & $2405(427.4)$ & $330(29.9)$ & $25(2.8)$ & $4(1.0)$ \\
\hline
\end{tabular}




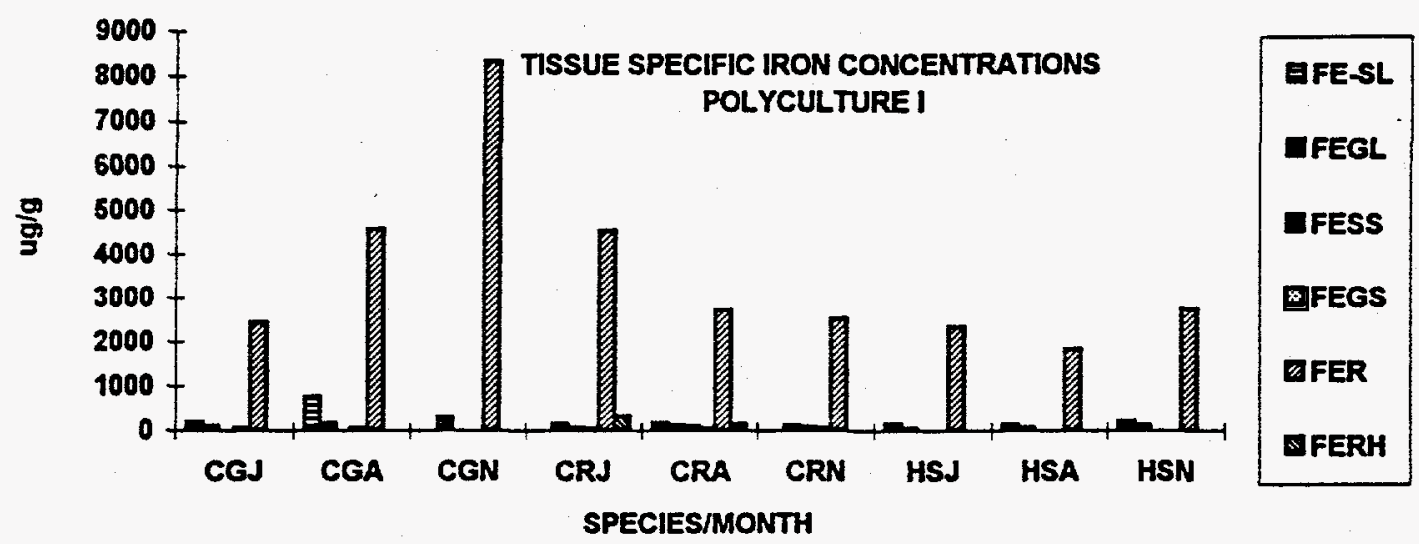

Fig. 4. Tissue specific concentrations of iron for canary grass (CG), common reed (CR), and hardstem bullrush (HS), during June (J), August (A), and November (N) 1993. Mean values are based on two-three samples per replicate cell $(\mathrm{n}=3)$ on each sample date. Tissues sampled include senescing leaves (FESL), green leaves (FEGL), senescing stems (FESS), green stems (FEGS), roots (FER) and rhizomes (FERH).

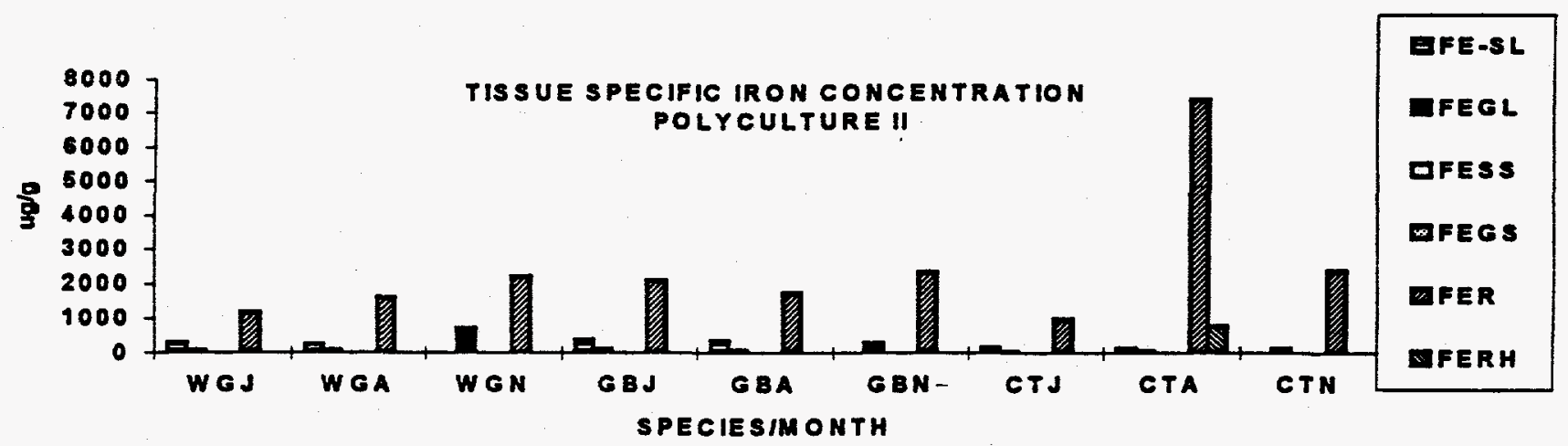

Fig. 5. Tissue specific concentrations of iron for woolgrass (WG), green bullrush (GB), and cattail (CT), during June (J), August (A), and November (N) 1993. Mean values are based on two-three samples per replicate cell $(n=3)$ on each sample date. Tissues sampled include senescing leaves (FESL), green leaves (FEGL), senescing stems (FESS), green stems (FEGS), roots (FER) and rhizomes (FERH).

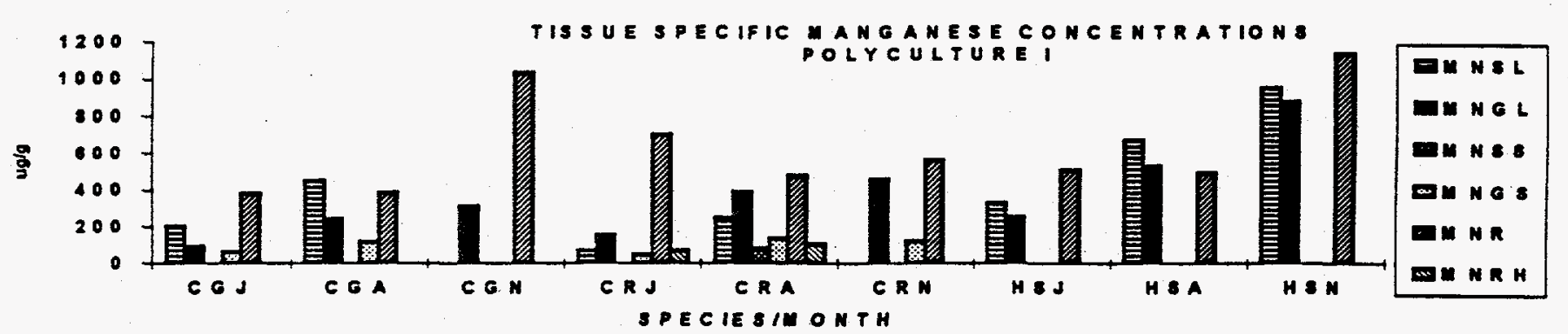

Fig. 6. Tissue specific concentrations of manganese for canary grass (CG), common reed (CR), and hardstem bullrush (HS), during June (J), August (A), and November (N) 1993. Mean values are based on two-three samples per replicate cell $(\mathrm{n}=3)$ on each sample date. Tissues sampled include senescing leaves (FESL), green leaves (FEGL), senescing stems (FESS), green stems (FEGS), roots (FER) and rhizomes (FERH). 


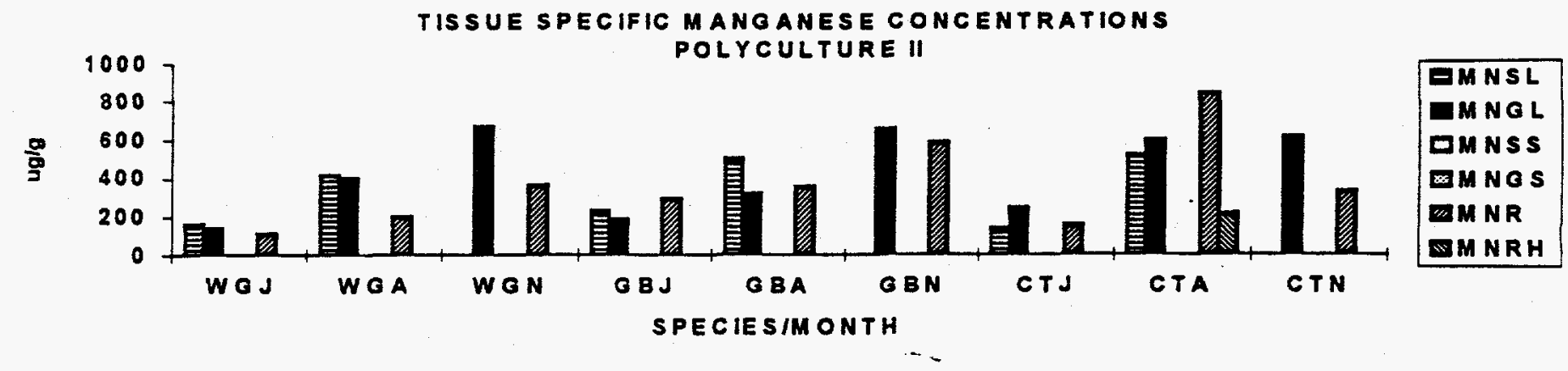

Fig. 7. Tissue specific concentrations of manganese for woolgrass (WG), green bullrush (GB), and cattail (CT), during June (J), August (A), and November (N) 1993. Mean values are based on two-three samples per replicate cell $(n=3)$ on each sample date. Tissues sampled include senescing leaves (FESL), green leaves (FEGL), senescing stems (FESS), green stems (FEGS), roots (FER) and rhizomes (FERH).

\section{SUMMARY AND CONCLUSIONS}

The role that aquatic macrophytes play in moderating water quality in constructed wetlands can be significant. Our findings, as well as those of others, indicate that plants can have a significant impact with respect to removing fertilizer nutrients and selected metals from polluted water. Although we did not attempt to calculate mass balances in this study, the biomass and tissue concentration data indicate that a significant portion of the nutrients and metals were either assimilated or sequestered by the plants. The complex nature of our results (species $x$ tissue $x$ season interactions), also indicate that additional emphasis needs to be placed on evaluation of plants in polyculture settings, It is important to understand the variation that exists within and among aquatic plant species with respect to nutrient /metal uptake rates, impact of season $\mathrm{x}$ species interactions, and the role that interspecific competition may have on these interactions. Many of the recent conferences in the United States have emphasized monoculture as a preferred and sustainable treatment strategy. However, based on the results of this study, we question whether a single species in a monoculture setting can impact water quality in the same way that a diverse array of compatible species can.

Our study was done under conditions that stimulate high levels of plant productivity and nutrient uptake: labile carbon source, high levels of nutrients, rapid water recirculation, and a relatively young stand of plants. Little organic matter buildup had taken place prior to initiation of the study. Long term studies need to be conducted to evaluate how plant productivity and wetland efficiency are influenced as a result of natural aging, organic matter accumulation, and inevitable plant succession. By understanding and controlling these factors, it will be possible to manage constructed wetlands to optimize improvements in water quality over a broad range of applications.

\section{ACKNOWLEDGEMENTS}

Appreciation is extended to Jerry Berry, Danny Williams and Eddie White for their tireless help in surveying plant stands, sampling plants and preparing tissue samples for analysis. We also acknowledge and thank Gene Ellison and other TVA associates who conducted 33 many analytical procedures required for this study.

\section{REFERENCES}

Armstrong, W. , (1975). Waterlogged soils, pp. 181-218 In J.R. Etherington (ed.), Environment and Plant Ecology. Wiley, London. 
Armstrong, W., Armstrong, J. and P.M. Beckett. (1990). Measurement and modelling of oxygen release from roots of Phragmites australis. pp. 41-51 In P.F. Cooper and B.C. Findlater (eds.) Constructed Wetlands in Water Pollution Control. Pergamon.

Boyd, C.E. (1970). Vascular aquatic plants for mineral nutrient removal from polluted waters. Econ. Bot. 24: $95-103$.

Breed, C. (1993). Constructed wetland R\&D facility at TVA's National Fertilizer and Environmental Research Center. pp. 369-372 In G.A. Moshiri (ed.), Constructed Wetlands for Water Quality Improvement. Lewis Publishers, Boca Raton, FL.

Brix, H. (1993). Macrophyte mediated oxygen transfer in wetlands: transport mechanisms and rates, pp. 391- 399 In G.A. Moshiri (ed.), Constructed Wetlands for Water Quality Improvement. Lewis Publishers, Boca Raton, FL.

Edwards, M.E., Brinkman, K.C. and Watson, J.T. (1993). Growth of soft-stem bulrush Scirpus validus plants in a gravel-based subsurface flow constructed wetlands. pp 415-425 In G.A. Moshiri (ed.), Constructed Wetlands for Water Quality Improvement. Lewis Publishers, Boca Raton, FL.

Faulkner S.P. and Richardson, C.J. (1994). Biogeochemistry of iron and manganese in selected TVA constructed wetlands receiving coal-mine drainage. Draft Final Report. Contract TV-72628A.

Gersberg, R.M., B.V. Elkins, S.R. Lyon, and C.R. Goldman. 1986. Role of Aquatic plants in wastewater treatment by artificial wetlands. Water Res., 20:363-368.

Johnston, Carol. (1991). Sediment and Nutrient retention by freshwater wetlands: effects on surface water quality. Critical Reviews in Environmental Control, 21(5,6):491-565.

Lakshman, G. (1987). Ecotechnological opportunities for aquatic plants- a survey of utilization options. pp. 46-68 In K.R. Reddy and W.H. Smith (Eds.) Aquatic Plants for Water Treatment and Resource Recovery. Magnolia Publishing Inc. Orlando, Florida.

Haberl, R and R. Perfler. (1989). Root-zone system: Mannersdorf - new results. pp 606-621 In Hammer, D. A. (Ed.) Constructed Wetlands for Wastewater Treatment: Municipal, Industrial, and Agricultural. Lewis Publishers, Inc., Chelsea, Michigan USA.

Jones J.B. and V.W. Case. 1990. Sampling, handling, and analyzing plant tissue samples, pp. 389-427 In Soil Testing and Plant Analysis. Soil Science Society of America, 3rd ed.-SSSA Book Series, no 3. Madison, WI.

Mart'in, I. and J. Ferna'ndez. (1992). Nutrient dynamics and growth of a cattail crop (Typha latifolia L.) developed in an effluent with high eutrophication potential - application to wastewater purification systems. Bioresource Technology 42:7-12.

Page, A.L., Miller R.H., and Keeney D.R. (eds). (1982). Soil Science Society of America, Madison Wis.

Reed, S.C. (1993). Subsurface flow constructed wetlonds for wastewater treatment: A technology assessment. EPA 832-R-93-001.

Reddy, K.R. and DeBusk W.F. (1985). Nutrient removal potential of selected aquatic macrophytes $J$. Environ. Qual. 14:459-462. 
Reddy, K.R and Debusk, W.F. (1987). Plant nutrient storage capabilities. pp. 337-359. In K.R. Reddy and W.H. Smith (Eds.) Aquatic Plants for Water Treatment and Resource Recovery. Magnolia Publishing Inc. Orlando, Florida

Sikora, F.J. (1994). Summary of research at the Tennessee Valley Authority's Constructed Wetlands research and Development Facility. Unpublished manuscript. Presented at Workshop on Constructed Wetlands for Animal Waste Management, Purdue University, April 4-6, 1994.

Sikora, F.J. Zhu Tong, Behrends, L.L., Steinberg, S.L., Coonrod,H.S., and L.G. Softley. (1994). Ammonium and phosphorus removal in constructed wetlands with recirculating subsurface flow: removal rates and mechanisms. For Inclusion in Proceedings 4th International Conference on Wetland Systems for Water Pollution Control, Nov. 1994, Guangzhou, China.

Steinberg S.L., and Coonrod, H.S. (1994). Oxidation of the root zone by aquatic plants growing in gravel/nutrient solution culture. J. Emviron. Qual. (in press). 